LOPES, CA; CARVALHO, ADF; PEREIRA, AS; AZEVEDO, FQ; CASTRO, CM; EMYGDIO, BM; SILVA, GO. 2021. Performance of Solanum phurejaderived bacterial-wilt resistant potato clones in a field naturally infested with Ralstonia solanacearum in Central Brazil. Horticultura Brasileira 39: 411-416. DOI: http://dx.doi.org/10.1590/s0102-0536-20210410

\title{
Performance of Solanum phureja-derived bacterial-wilt resistant potato clones in a field naturally infested with Ralstonia solanacearum in Central Brazil
}

\author{
Carlos A Lopes ${ }^{1} \mathbb{D}$; Agnaldo DF Carvalho ${ }^{1} \mathbb{D}$; Arione S Pereira ${ }^{2} \mathbb{D}$; Fernanda Q Azevedo ${ }^{2} \mathbb{D}$; Caroline $M$ \\ Castro $^{2} \mathbb{D}$; Beatriz $M$ Emygdio $^{2} \mathbb{D}$; Giovani O Silva ${ }^{1} \mathbb{D}$
}

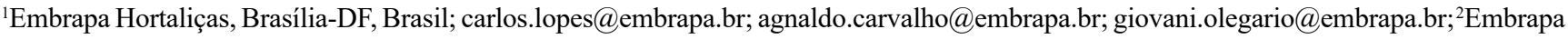
Clima Temperado, Pelotas-RS, Brasil; arione.pereira@embrapa.br; caroline.castro@embrapa.br; fernanda.azevedo@embrapa.br; beatriz. emygdio@embrapa.br

\begin{abstract}
Bacterial wilt (BW), or brown rot, caused by the soil and seed borne bacterium Ralstonia solanacearum, is one of the most devastating diseases of potatoes cultivated in warmer regions of the world. There are no potato cultivars with a desirable level of BW resistance, although it has been recognized that resistance can be an outstanding component for disease management. However, the sources of resistance available lack agronomic traits required by potato growers, therefore being of little interest to breeders. The objective of this work was to evaluate the performance of 11 clones selected for BW resistance and improved for tuber traits upon selection in the last two decades. The clones under test were compared with susceptible and resistant clones and cultivars, in a completely randomized blocks design with three replications of single lines of 10 plants, in a field naturally infested with race 1 , biovar 1 , phylotype II of $R$. solanacearum. BW incidence was assessed 60-70 days after planting and total tuber yield in each plot was recorded 110 days after planting. All the evaluated clones presented higher levels of resistance to BW compared with the commercial varieties, not differing from the resistant, not commercial, controls. In a next step, these clones will be characterized for other desirable traits and those which combine high level of resistance and commercial characteristics will be recommended for breeders for enriching the genotypic background in the search for commercial varieties. We also confirmed that the cultivar BRSIPR Bel displays an intermediate level of resistance, what makes it an interesting genitor for its good agronomic characteristics. The findings of this work demonstrate that the improved potato clones selected under tropical conditions in the Embrapa's pre-breeding project possess high and stable levels of resistance to bacterial wilt, being a valuable resource for breeders.
\end{abstract}

Keywords: Solanum tuberosum, brown rot, resistance.

\section{RESUMO}

Comportamento de clones de batata resistentes à murcha bacteriana, derivados de Solanum phureja, em campo naturalmente infestado com Ralstonia solanacearum no Brasil Central

A murcha bacteriana (MB), ou murchadeira, causada pela bactéria Ralstonia solanacearum e transmitida pelo solo e pela semente, é uma das doenças mais devastadoras da batata cultivada nas regiões mais quentes do mundo. Seu controle é muito difícil e não existem cultivares resistentes a ela, embora a resistência seja reconhecida como importante componente para o manejo integrado da doença. No entanto, as fontes de resistência à MB disponíveis até então apresentam muitas características indesejáveis, sendo, por isso, de pouco interesse aos melhoristas que têm o foco no desenvolvimento de genótipos de interesse comercial. O objetivo deste trabalho foi de avaliar 11 clones selecionados nas duas últimas décadas na Embrapa Hortaliças para resistência à $\mathrm{MB}$ e, ao mesmo tempo, com seleção leve para algumas características comerciais durante os ciclos de seleção. O nível de resistência dos clones foi avaliado por quatro anos consecutivos em área experimental naturalmente infestada com a raça 1, biovar 1, filotipo II de $R$. solanacearum. Como testemunhas, foram usados clones ou cultivares previamente identificados como resistentes ou suscetíveis. O delineamento experimental foi de blocos ao acaso com três repetições e parcelas de 10 plantas, em linha única. A avaliação foi feita pela incidência da doença no período de 60 a 70 dias após o plantio e a produção total de tubérculos nas parcelas registrada 110 dias após o plantio. Todos os clones avaliados apresentaram níveis de resistência superiores aos das cultivares mais plantadas no Brasil e não diferiram das testemunhas resistentes. Como somente a resistência não basta para ser um bom progenitor, esses clones serão avaliados para as características comerciais de maior relevância aos programas de melhoramento. Em adição, foi confirmada a resistência intermediária da cultivar BRSIPR Bel, o que a torna um genitor de interesse pelas suas ótimas características comerciais. Este trabalho demonstrou que clones selecionados na Embrapa para resistência à $\mathrm{MB}$ em condições tropicais apresentam alto e estável grau de resistência e podem vir a ser usados, de imediato ou após novos ciclos de seleção, em programas de melhoramento visando ao desenvolvimento de cultivares.

Palavras-chave: Solanum tuberosum, murchadeira, resistência.

Received on May 24, 2021; accepted on October 21, 2021 
G rowers worldwide live with an already existing risk of cultivating potatoes (Solanum tuberosum) in regions and seasons with environmental conditions which deviate from the ideal for the crop. This is especially relevant in tropical and subtropical regions like those that occur in Brazil. These conditions favor the establishment and the intensity of diseases like bacterial wilt (BW), or brown rot, caused by the soil and seed borne bacterium Ralstonia solanacearum, one of the most devastating diseases of potatoes cultivated in warmer regions of the world (Lopes et al., 2011; Yuliar \& Toyota, 2015; Lopes \& Rossato, 2018; Elphinstone, 2020).

BW induces foliage wilt followed by plant death and tuber rotting, resulting in yield losses that can reach up to $80 \%$ in a susceptible cultivar whenever environmental conditions are favorable for disease onset and spread (Champoiseau et al., 2009). But economic losses can be even greater, since the bacterium infests the soil, making it impossible to grow many susceptible Solanaceae species for years (Elphinstone, 2020).

Although cultural practices, such as crop rotation, planting season and use of disease-free seeds are control measures that significantly contribute to reduce bacterial wilt losses, host plant resistance can be an additional effective strategy for fighting the disease (Mihovilovich et al., 2017; Muthoni et al., 2020). However, there are no major potato cultivars worldwide reliably resistant to BW, even though different responses on susceptibility degrees are observed. Unfortunately, the available partial resistance is not enough to protect the crop in excessively hot or wet conditions (Carvalho et al., 2017; Elphinstone, 2020; Muthoni et al., 2020).

The genetic control of BW resistance is particularly complex in tetraploid species like potato, where resistance genes are found in wild species usually linked to undesirable traits (Schmiediche \& Martin, 1986; Tung et al., 1993; Patil et al., 2012; Muthoni et al., 2020). This linkage usually makes breeders to avoid wild species as genitors, preferring agronomically advanced materials (Iqbal et al., 2013).

Resistance is usually linked with undesirable traits in wild potato species and on Cruza 148, the most known genotype in the world for being cultivated in some African countries mainly because of its resistance to BW and late blight (Phythophtora infestans) (Schmiediche \& Martin, 1986; Tung et al., 1993; Patil et al., 2012; Gutarra et al., 2015).

Systematic efforts to obtain BWresistant cultivars have been carried out the last five decades, after high levels of resistance were identified in Solanum phureja diploid clones (Sequeira \& Rowe, 1969; Schmiediche, 1986). This source of resistance was found to be dominant and readily transferred to commercial cultivars of $S$. tuberosum without carrying some of the undesirable traits found in wild species (Schmiediche \& Martin, 1986; French et al., 1998).

In order to improve the agronomic characteristics of resistant clones, Embrapa's pre-breeding program for BW resistance started in the early 1980 's in a close collaboration with the International Potato Center (CIP) and relied on crosses of commercial cultivars of $S$. tuberosum mainly with clones of $S$. phureja. Resistant clones were selected following a protocol that started from artificial inoculation of seedlings in a greenhouse followed by a series of greenhouse and field multiplications and selection (Mihovilovich et al., 2017; Lopes et al., 2018). This protocol allowed the combination of BW resistance with good agronomic and quality traits; thus, the advanced clones can be used by breeders in new crossings in selection cycles or eventually be released as cultivars.

The objective of this work was to evaluate the BW field resistance of 11 clones selected for BW resistance and commercial traits in the last two decades in a pre-breeding section of Embrapa's potato breeding program.

\section{MATERIAL AND METHODS}

\section{Tested clones}

The BW-resistant potato clones, MB54-2, MBF21-05, MBF3-03, MBF306, MBF6-03, MBF6-07, MBF9-01, MBF9-02, MB195-10, MB57-32, and MB9846-01 were obtained from true seeds of populations derived from crosses involving S. tuberosum cultivars (or advanced clones from Brazilian Breeding Program) and BW-resistant clones which resistance was derived from $S$. phureja. These clones are result of a pre-breeding project for BW resistance started at Embrapa Hortaliças in the 1980's in close cooperation with the International Potato Center (CIP), Lima, Peru, following a selection protocol developed and adjusted to meet the demands of the Brazilian market of fresh and processing potatoes (Lopes et al., 2018). This protocol consists of crossing BW resistant clones with cultivars or advanced clones and the progeny challenged at the seedling stage with artificial inoculation with $R$. solanacearum under greenhouse. The surviving putative resistant clones are then exposed in a field naturally infested with race 1 , biovar 1 , phylotype II (R1B1P2) of $R$. solanacearum (Lopes et al., 2018), where, besides evaluated for resistance, they are selected (visual light selection) especially for yield and tuber type. A new cycle of selection is started, crossing the best selected clones with different commercial variety or advanced clone in order to avoid genetic depression by endogamy (Mihovilovich et al., 2017; Lopes et al., 2018). With this methodology, besides BW resistance, we performed selection for tuber commercial traits in conformity with the goals established in Embrapa's potato breeding project coordinated by Embrapa Clima Temperado.

\section{Seed production}

To avoid latent infection which could interfere with disease onset, tubers used as seeds for the experiments were produced in the previous years in a field at Embrapa Hortaliças without recent history of bacterial wilt. The exception was in 2020, when apparently healthy tubers of 'BRSPR Bel' and the resistant controls 'MB-03' and 'Cruza 148' were saved from the infested plot in the same period of 2019. Tubers were harvested in August/September and maintained in 
a cold chamber $\left(3-10^{\circ} \mathrm{C}\right)$.

\section{Assessment of bacterial wilt} resistance

The advanced 11 resistant clones were evaluated at Embrapa Hortaliças, Brasília, DF, Brazil (15 ${ }^{\circ} 56^{\prime} \mathrm{S}, 48^{\circ} 08^{\prime} \mathrm{W}$, $998 \mathrm{~m}$ altitude) in the period of MayAugust of 2017 to 2020 in a field naturally infested with R1B1P2 of $R$. solanacearum, which is prevalent in warmer regions/countries (Lopes et al., 2018, Muthoni et al., 2020). The experiments consisted of plots of 10-plant single lines with three replications in a RCBD. The susceptible controls were 'Agata' and 'Asterix', Dutch cultivars most planted in Brazil for fresh market and processing, respectively, and 'Monalisa', that was widely cultivated in Brazil in the past and was replaced by other cultivars partly due to its high susceptibility to BW (Silveira et al., 2007; Lopes et al., 2018). Resistant controls consisted of clones MB-03, selected at Embrapa, and Cruza 148, provided by CIP as an international resistant control. Both clones are highly resistant to $\mathrm{BW}$, but lack important commercial traits (Silveira et al., 2007; Lopes et al., 2018). The Brazilian potato cultivar BRSIPR Bel, which displayed an intermediate level of resistance to BW in a preliminary study (Carvalho et al., 2017), was also used as control.

The plants were grown according to local standard fertilization and foliar pest control procedures in order to obtain acceptable yield. Disease incidence ( $\%$ of wilted plants) was measured 60 to 70 days after planting, depending on the year, as soon as at least $80 \%$ of the plants of susceptible controls were wilted, occasion that clearly distinguished resistance levels among the genotypes. Plants were harvested 110 days after planting, 10 days after a desiccant application, and the total tuber yield in each plot was recorded (Lopes et al., 2018).

The data of percentage of incidence of BW and of total tuber yield per plot of each year were individually submitted to the analysis of variance, after tested for normality, and transformed by $\sqrt{x+0,5}$ when needed. A joint analysis of the four years was performed using the SAS v. 8.2 software (Muller \& Fetterman, 2003). The single effects of the variable clones, year of evaluation and the interactions, whenever significant, were split and grouped by the Scott-Knott test at $5 \%$ probability level, using the Genes v. 1990.2019.120 software (Cruz, 2013).

\section{RESULTS AND DISCUSSION}

Typical BW symptoms developed in the $R$. solanacearum infested area in all four years of testing, therefore allowing the observation of differences in resistance levels among the potato genotypes. Even though the disease intensity varied among years, due to differences in temperature and late rainfalls which affected disease onset and development, genotype reactions were consistent (Table 1). All clones previously selected for BW resistance were significantly different from the commercial susceptible controls, 'Asterix', 'Agata', and 'Monalisa' - the latter a commercial susceptible cultivar replaced by 'Agata', and did not differ from the resistant controls, 'Cruza 148' and 'MB 03' (Table 1).

All these BW resistant clones presented also higher total tuber yield than the susceptible cultivars, and as a result of more plant survival in the field, highlighting for this trait the clones MB54-02, MBF3-06, MB19510, MB57-32, MB9846-01, and the standard BW resistant control MB-03 (Table 2).

These results, therefore, indicate striking differences observed between the susceptible controls, displaying high disease incidences and practically no yield, and the resistant clones, with yields close or higher than $1 \mathrm{~kg} / \mathrm{plant}$ due to high plant survival (Tables 1 and 2).

The Brazilian cultivar BRSIPR Bel

Table 1. Means of bacterial wilt incidence (\%) of potato clones and cultivars cultivated for four consecutive years in a field plot infested with Ralstonia solanacearum in Brasilia, DF. Brasilia, Embrapa Hortaliças, 2017-2020.

\begin{tabular}{lcrcc}
\hline \multirow{2}{*}{ Clone/cultivar } & \multicolumn{5}{c}{ Year } \\
\cline { 2 - 5 } & \multicolumn{1}{c}{$\mathbf{2 0 1 7}$} & $\mathbf{2 0 1 8}$ & $\mathbf{2 0 1 9}$ & $\mathbf{2 0 2 0}$ \\
\hline MB54-02 & - & $5.24 \mathrm{Bd}$ & $17.12 \mathrm{Ac}$ & $12.97 \mathrm{Ac}$ \\
Agata* & $73.02 \mathrm{Aa}$ & $100.00 \mathrm{Aa}$ & $100.00 \mathrm{Aa}$ & $75.21 \mathrm{Aa}$ \\
Asterix* & $59.72 \mathrm{Bb}$ & $96.61 \mathrm{Aa}$ & $100.00 \mathrm{Aa}$ & $71.91 \mathrm{Aa}$ \\
BRSIPR Bel & $48.87 \mathrm{Bb}$ & $41.37 \mathrm{Bb}$ & - & $93.09 \mathrm{Aa}$ \\
Cruza 148** & $21.83 \mathrm{Ac}$ & $10.09 \mathrm{Bd}$ & $5.24 \mathrm{Bd}$ & $16.42 \mathrm{Ac}$ \\
MBF21-05 & - & $49.81 \mathrm{Ab}$ & $56.52 \mathrm{Ab}$ & $16.30 \mathrm{Bc}$ \\
MBF3-03 & $14.85 \mathrm{Bc}$ & $42.78 \mathrm{Ab}$ & $65.64 \mathrm{Ab}$ & - \\
MBF3-06 & $3.42 \mathrm{Cd}$ & $17.83 \mathrm{Bc}$ & $39.58 \mathrm{Ab}$ & $12.36 \mathrm{Bc}$ \\
MBF6-03 & $1.91 \mathrm{Cd}$ & $36.11 \mathrm{Ab}$ & $19.13 \mathrm{Bc}$ & $10.09 \mathrm{Cd}$ \\
MBF6-07 & $1.91 \mathrm{Bd}$ & $12.97 \mathrm{Ac}$ & $7.48 \mathrm{Bd}$ & $12.97 \mathrm{Ac}$ \\
MBF9-01 & $1.91 \mathrm{Bd}$ & $19.13 \mathrm{Ac}$ & $10.00 \mathrm{Bd}$ & $12.36 \mathrm{Ac}$ \\
MBF9-02 & $24.93 \mathrm{Bc}$ & $36.11 \mathrm{Ab}$ & $57.72 \mathrm{Ab}$ & $17.12 \mathrm{Bc}$ \\
MB-03** & $0.00 \mathrm{Bd}$ & $5.24 \mathrm{Bd}$ & $20.00 \mathrm{Ac}$ & $7.48 \mathrm{Bd}$ \\
MB195-10 & $1.91 \mathrm{Bd}$ & $14.45 \mathrm{Ac}$ & $7.48 \mathrm{Bd}$ & $7.48 \mathrm{Bd}$ \\
MB57-32 & $21.69 \mathrm{Ac}$ & - & $28.52 \mathrm{Ac}$ & - \\
MB9846-01 & $22.18 \mathrm{Ac}$ & $9.46 \mathrm{Bd}$ & $23.11 \mathrm{Ac}$ & $25.92 \mathrm{Ac}$ \\
Monalisa* & $100.00 \mathrm{Aa}$ & $100.00 \mathrm{Aa}$ & $100.00 \mathrm{Aa}$ & - \\
\hline General mean & 26.54 & 37.33 & 41.40 & 27.98 \\
CV (\%) & 34.49 & 24.07 & 25.17 & 41.23 \\
\hline Si & & &
\end{tabular}

Same capital letter in the line and small letter in the column belong to the same group (ScottKnott 5\%); -= Not evaluated; *Susceptible controls; **Resistant controls. 
confirmed its intermediate resistance level in two of the three years. The high incidence of the disease in 2020 is explained by the presence of latent infection in the seeds, since the tubers available for planting this year were saved from a plot where BW occurred (Ciampi et al., 1980). This cultivar has oblong tuber format, good tuber appearance and high values of tuber yield and specific gravity or tuber dry matter content, and low level of sugars, being released as a cultivar mainly for frying chips (Pereira et al., 2015). It was not selected for BW resistance in its development process, but has consistently shown some tolerance to the disease possibly due to a fortuitous gene combination (Carvalho et al., 2017). This result reinforces the importance of using "clean" seeds in potato production and the "zero tolerance" for BW in the seed certification process (MAPA, 2021).

It has been reported that the genetic background of the commercial genitor used in the recurrent selection contributes with the level of resistance of the progenies (Tung et al., 1990). For example, when a BW-resistant clone is crossed with a cultivar selected under tropical conditions and, additionally, displays an intermediate level of BW resistance, such as 'BRSIPR Bel', the family yields higher numbers of clones which survive on soils infested with $R$. solanacearum (Carvalho et al., 2017). That is why 'BRSIPR Bel' has been one of the main progenitors for BW resistance used at the Embrapa's breeding program since it was released, highlighting the performance of the clone MB 54-02 in this study.

Partial resistance has been reported in commercially acceptable $S$. tuberosum genotypes not bred for BW resistance, such as 'Ontario' and 'Prisca' in Papua New Guinea and Madagascar, respectively (Nielsen \& Haynes, 1960; French, 1994; Norman et al., 2020); 'Araucaria', 'Achat' and 'Granola' (Lopes \& Quezado-Soares, 1995; Quezado-Duval \& Lopes, 1999; Silveira et al., 2007), 'Désirée', 'Kennebec', 'Red Norland', and 'Red Pontiac' in the USA (Norman et al., 2020).

The main reason for the slow advance

Table 2. Means of total tuber yield (kg/10 plants) of potato clones and cultivars cultivated for four consecutive years in a field plot infested with Ralstonia solanacearum in Brasilia, DF. Brasilia, Embrapa Hortaliças, 2017-2020.

\begin{tabular}{|c|c|c|c|c|c|c|c|c|}
\hline \multirow{3}{*}{$\begin{array}{l}\text { Clone/cultivar } \\
\text { MB54-02 }\end{array}$} & \multicolumn{8}{|c|}{ Year } \\
\hline & \multicolumn{2}{|c|}{2017} & \multicolumn{2}{|c|}{2018} & \multicolumn{2}{|c|}{2019} & \multicolumn{2}{|c|}{2020} \\
\hline & - & & 11.47 & $\mathrm{Aa}$ & 6.67 & $\mathrm{Aa}$ & 8.33 & $\mathrm{Aa}$ \\
\hline Agata* & 0.54 & $\mathrm{Bd}$ & 0.00 & $\mathrm{Bd}$ & 0.45 & $\mathrm{Bd}$ & 1.63 & Ac \\
\hline Asterix* & 0.88 & $\mathrm{Bd}$ & 0.43 & $\mathrm{Bd}$ & 0.12 & $\mathrm{Bd}$ & 1.65 & Ac \\
\hline BRSIPR Bel & 2.52 & $\mathrm{Bc}$ & 4.00 & $\mathrm{Ab}$ & - & & 0.30 & $\mathrm{Cd}$ \\
\hline Cruza $148^{* *}$ & 2.47 & $\mathrm{Cc}$ & 7.83 & $\mathrm{Aa}$ & 7.09 & $\mathrm{Aa}$ & 5.39 & $\mathrm{Bb}$ \\
\hline MBF21-05 & - & & 6.19 & $\mathrm{Ab}$ & 3.97 & $\mathrm{Ab}$ & 5.86 & $\mathrm{Ab}$ \\
\hline MBF3-03 & 4.80 & $\mathrm{Ab}$ & 3.61 & $\mathrm{Ab}$ & 2.52 & $\mathrm{Bc}$ & 0.00 & $\mathrm{Cd}$ \\
\hline MBF3-06 & 12.46 & $\mathrm{Aa}$ & 6.84 & $\mathrm{Aa}$ & 9.47 & $\mathrm{Aa}$ & 9.30 & $\mathrm{Aa}$ \\
\hline MBF6-03 & 4.77 & $\mathrm{Ab}$ & 3.81 & $\mathrm{Ab}$ & 4.05 & $\mathrm{Ab}$ & 3.21 & $\mathrm{Ab}$ \\
\hline MBF6-07 & 7.83 & Aa & 5.94 & $\mathrm{Bb}$ & 5.90 & $\mathrm{Bb}$ & 5.48 & $\mathrm{Bb}$ \\
\hline MBF9-01 & 7.41 & $\mathrm{Aa}$ & 5.73 & $\mathrm{Bb}$ & 3.66 & $\mathrm{Bb}$ & 3.94 & $\mathrm{Bb}$ \\
\hline MBF9-02 & 7.08 & $\mathrm{Aa}$ & 5.89 & $\mathrm{Bb}$ & 2.60 & $\mathrm{Cc}$ & 7.43 & $\mathrm{Aa}$ \\
\hline MB- $03 * *$ & 10.31 & Aa & 11.38 & $\mathrm{Aa}$ & 6.21 & $\mathrm{Bb}$ & 10.06 & $\mathrm{Aa}$ \\
\hline MB195-10 & 7.68 & $\mathrm{Aa}$ & 6.96 & $\mathrm{Aa}$ & 7.27 & $\mathrm{Aa}$ & 6.69 & $\mathrm{Aa}$ \\
\hline MB57-32 & 8.53 & Aa & - & & 7.76 & Aa & - & \\
\hline MB984601 & 9.04 & $\mathrm{Aa}$ & 7.28 & $\mathrm{Aa}$ & 9.78 & $\mathrm{Aa}$ & 9.28 & $\mathrm{Aa}$ \\
\hline Monalisa* & 0.00 & Ad & 0.00 & Ad & 0.00 & $\mathrm{Ad}$ & - & \\
\hline General mean & 5.75 & & 5.46 & & 4.85 & & 5.24 & \\
\hline $\mathrm{CV}(\%)$ & 13.49 & & 18.52 & & 20.50 & & 23.74 & \\
\hline
\end{tabular}

Same capital letter in the line and small letter in the column belong to the same group (ScottKnott 5\%); -= Not evaluated; *Susceptible controls; **Resistant controls.

in the development of BW-resistant potato cultivars is that the control of the resistance is polygenic, what constraints the transfer of the identified quantitative trait loci into desirable genotypes especially in tetraploid species. In addition, these loci are usually linked to undesirable traits found in the wild species used as sources of resistance, such as glycoalkaloid content, stolon length, eye depth, and tuber shape (Schmiediche \& Martin, 1986; French et al., 1998; Patil et al., 2012; Lopes et al., 2018; Muthoni et al., 2020).

Even though the resistant clones selected in Brasilia have not been tested in different potato-producing regions, we believe that the resistant from $S$. phureja, like the one found in clone MB-03, can withstand other variants of the pathogen. Silveira et al. (2007) evaluated the clones Cruza 148 and MB-03 and reported that they were significantly more resistant to bacterial wilt than other clones and cultivars in a soil naturally infested with $R$. solanacearum race 3 , biovar 2, phylotype II in Rio Grande do Sul state in the South of the country. Cruza 148 , of unknown origin, probably from a cross between $S$. tuberosum and $S$. demissum (Schmiediche, 1986; Muthoni et al., 2020) is the most known BWresistant variety available in the world (Gutarra et al., 2015), being cultivated in some African countries and having resistance also to late blight caused by Phythophtora infestans (Wulff et al., 2007). Unfortunately, it also carries many undesirable genes that makes it an unacceptable genitor in breeding programs (Tung et al., 1990).

Worldwide, BW pre-breeding programs have not reported advanced promising resistant genitors suitable for cultivar development programs due to unstable resistance and undesirable tuber traits, what frustrate breeders who search for introgressing BW resistance in tropical-adapted commercial genotypes 
(Lopes et al., 2018; Muthoni et al., 2020; Norman et al., 2020). In the present work, we observed good levels of resistance to $\mathrm{BW}$, not differing from the resistant controls 'Cruza 148 ' and 'MB-03', mainly the clones MB5402, MBF3-06, MB1950-10, MB5732, MB9846-01, and the standard resistant control 'MB-03'. Resistance on all of them is derived from $S$. phureja, mainly present on 'MB984601 ', which consistently performed as a good genitor for BW breeding programs. These resistant clones will be further characterized for the most relevant commercial traits, and those which combine high resistance with desirable traits, will be recommended to breeders for the next cycles of selection and for widening the genetic background of the genitors. We also confirmed that the cultivar BRSIPR Bel displays an intermediate level of resistance, being also an interesting parental clone as it has good agronomic characteristics. The findings of this work demonstrate that the improved potato clones selected under tropical conditions in the Embrapa's pre-breeding project in the last decades can be used in breeding programs as sources of high and stable resistance to BW under field conditions.

\section{ACKNOWLEDGMENTS}

To the Brazilian National Council for Scientific and Technological Development $(\mathrm{CNPq})$, for financial support; To the International Potato Center, for providing germplasm and technical support; To the Research and Rural Extension Company of Santa Catarina (EPAGRI) for collaboration on the first crossings.

\section{REFERENCES}

CARVALHO, ADF; LOPES, CA; RAGASSI, CF. 2017. Desempenho de cultivares de batata sob diferentes espaçamentos em solo naturalmente infestado com Ralstonia solanacearum. Horticultura Brasileira 35: 507-511. DOI - http://dx.doi.org/10.1590/ S0102-053620170406

CHAMPOISEAU, PG; JONES, JB; ALLEN C. 2009. Ralstonia solanacearum race 3 biovar 2 causes tropical losses and temperate anxieties.
Online. Plant Health Progress. American Phytopathological Society. Madison, WI, USA. Available at: $<\mathrm{https}$ ://apsjournals.apsnet. org/doi/abs/10.1094/PHP-2009-0313-01-RV>. Accessed on March 18, 2021.

CIAMPI, L; SEQUEIRA, L; FRENCH, ER. 1980. Latent infection of potato tubers by Pseudomonas solanacearum. American Potato Journal 57: 377-386.

CRUZ, CD. 2013. GENES - a software package for analysis in experimental statistics and quantitative genetics. Acta Scientiarum 35: 271-276.

ELPHINSTONE, JG. s/d. Estimating yield loss in potato due to bacterial wilt caused by Pseudomonas solanacearum. Available at: <https://www.jircas.go.jp/sites/default/ files/publication/tars/tars22-_120-130.pdf $>$. Accessed on Abril 15, 2020.

FRENCH, ER. 1994. Strategies for integrated control of bacterial wilt of potatoes. Pages 199-207 In: HAYWARD, AC; HARTMAN, GL (eds). Bacterial wilt: the disease and its causative agent, Pseudomonas solanacearum. Wallingford: CAB International, 1994.

FRENCH, ER; ANGUIZ, R; ALEY, P. 1998. The usefulness of potato resistance to Ralstonia solanacearum for the integrated control of bacterial wilt. p.381-385 IN: PRIOR, PH; ALLEN C; ELPHINSTONE J (eds). Bacterial wilt disease: Molecular and ecological aspects. Report of the Second International Wilt Symposium, Gosier, Guadeloupe, France. Springer-Verlag, Berlin, Germany.

GUTARRA, L; KREUZE, J.; LINDQVISTKREUZE, H; MENDIBURU, F. 2015. Variation of resistance to different strains of Ralstonia solanacearum in highland tropics adapted potato genotypes. American Journal of Potato Research 92: 258-265.

IQBAL, AM; LONE, AA; WANI, SA; WANI, SH; NEHVI, FA. 2013. Pre-breeding and population improvement. LS - An International Journal of Life Sciences 2: 188-197. DOI: 10.5958/j.2319-1198.2.2.012

LOPES, CA; QUEZADO-SOARES, AM. 1995. Estabilidade da resistência da batata 'Achat' à murcha-bacteriana. Horticultura Brasileira 13: $57-58$

LOPES CA; SILVA GO; CRUZ EM; ASSAD E; PEREIRA AS. 2011. Uma análise do efeito do aquecimento global na produção de batata no Brasil. Horticultura Brasileira 29: 7-15.

LOPES, CA; ROSSATO, M. 2018. History and status of selected hosts of the Ralstonia solanacearum species complex causing bacterial wilt in Brazil. Frontiers in Microbiology 9: 1228. DOI: 10.3389/ fmicb.2018.01228.

LOPES, CA; MELO, PE; ROSSATO, M; PEREIRA, AS. 2018. Breeding potatoes for resistance to bacterial wilt in Brazil: a quick review in face of a more effective screening protocol. Horticultura Brasileira 36: 6-12. DOI: http://dx.doi.org/10.1590/ S0102-053620180102

MAPA. Normase padrões deproduçãoe importação de batata-semente. Available at: <https:// www.gov.br/agricultura/pt-br/assuntos/ insumos-agropecuarios/insumos-agricolas/ sementes-e-mudas/publicacoes-sementes-emudas/INN32de20denovembrode2012.pdf> Accessed on January 12, 2021.

MIHOVILOVICH, E; LOPES, C; GUTARRA, L; LINDQVIST-KREUZE, H; ALEY, P; PRIOU, S; BONIERBALE, M. 2017. Protocol for assessing bacterial wilt resistance in greenhouse and field conditions. International Potato Center. Available at: $<$ https://cgspace. cgiar.org/bitstream/handle/10568/83310/CIPProtocol-assessing-bacterial-wilt resistance. pdf;jsessionid=7ADEE4308F1DF840EFC9 D793F7472B89? sequence $=6>$. ISBN 97892-9060-214-9. 35 p. Accessed on November 10, 2020.

MULLER, KE; FETTERMAN, BA. 2003. Regression and ANOVA: An integrated approach using SAS Software. New York: John Wiley \& Sons. 592p.

MUTHONI, J; SHIMELIS, H; MELIS, R. 2020. Conventional breeding of potatoes for resistance to bacterial wilt (Ralstonia solanacearum): Any light in the horizon? Australian Journal of Crop Science 14: 485-494.

NIELSEN, LW; HAYNES, FL. 1960. Resistance in Solanum tuberosum to Pseudomonas solanacearum. American Potato Journal 37: 260-267.

NORMAN, DJ; YUEN, JMF; BOCSANCZY, AM. 2020. Threat of brown rot of potato and existing resistance. American Journal of Potato Research 97: 272-277. https://doi. org/10.1007/s12230-020 -09775-3

PATIL, VU; GOPAL, J; SINGH BP. 2012. Improvement for bacterial wilt resistance in potato by conventional and biotechnological approaches. Agricultural Research 1: 299-316.

PEREIRA, AS; NAZARENO, NR; SILVA, GO; BERTONCINI, O; CASTRO, CM; HIRANO, E; ANTONIO C BORTOLETTO, AC; TREPTOW, RO; DUTRA, LF; LIMA, MF; GOMES, CB; KROLOW, A.C.R; MEDEIROS, CAB; CASTRO, LAS; SUINAGA, FA; LOPES, CA; MELO, PE. 2015. BRSIPR Bel: Cultivar de batata para chips com tubérculos de boa aparência. Horticultura Brasileira 33:135-139.

QUEZADO-DUVAL, AM; LOPES, CA. 1999. Desempenho de cultivares de batata em solo infestado com Ralstonia solanacearum, raça 1. Horticultura Brasileira 17: 244-247.

SCHMIEDICHE, P. 1986. Breeding potatoes to bacterial wilt caused by Pseudomonas solanacearum. P.105-111 IN: PERSLEY, JG (ed). Bacterial Wilt in Asia and the South Pacific. Proceedings of an international workshop held at PCARRD, Los Baños, Philippines. 145p.

SCHMIEDICHE, P; MARTIN, C. 1986. The use of wild species in breeding for resistance to bacterial wilt (Pseudomonas solanacearum). American Potato Journal 63: 453.

SEQUEIRA, L; ROWE, PR. 1969. Selection and utilization of Solanum phureja clones with high resistance to different strains of Pseudomonas solanacearum. American Potato Journal 46: 451-462. 
SILVEIRA, JRP; DUARTE, V; MORAES, MG; LOPES, CA; FERNANDES, JM; BARNI, V; MACIEL, JLN. 2007. Epidemiological analysis of clones and cultivars of potato in soil naturally infested with Ralstonia solanacearum biovar 2. Fitopatologia Brasileira 32: 181-188.

TUNG, PX.; RASCO, ET; ZAAG, PV; SCHMIEDICHE, P. 1990. Resistance to
Pseudomonas solanacearum in the potato: I. Effects of sources of resistance and adaptation. Euphytica 45: 203-210.

TUNG, PX; HERMSEN, JG; VANDER, PZ; SCHMIEDICHE, PE. 1993. Inheritance of Resistance to Pseudomonas solanacearum in tetraploid potato. Plant Breeding 111: 23-30.

WULFF, EG; PÉREZ, W; NELSON, RJ; BONIERBALE, M; LANDEO JA; FORBES,
GA. 2007. Identification of stable resistance to Phytophthora infestans in potato genotypes evaluated in field experiments in Peru. Experimental Agriculture 43: 353-363. https:// doi.org/10.1017/S0014479707004991

YULIAR, Y; TOYOTA, K. 2015. Recent trends in control methods for bacterial wilt diseases caused by Ralstonia solanacearum. Microbes and Environments 30: 1-11. 